\title{
Pattern Design for Asymmetric Bodies: Garments Custom-Made, Altered, or Made-To-Measure to Fit Individuals with Asymmetric Body Figures
}

\author{
Maria Tsakalidou* \\ Fashion Design and Marketing, Aristotle University of Thessaloniki, Greece
}

Submission: October 27, 2017; Published: November 27, 2017

*Corresponding author: Maria Tsakalidou, Fashion Design and Marketing, Aristotle University of Thessaloniki, Pavlou Mela str. - 54622

Thessaloniki, Greece, Tel: 0030-2310-254-447; Email: fff@hol.gr

\section{Perspective}

Dressing requires finding clothes that fit our bodies and the way we look, as well as the society and occasions we are part of [1]. The fit of a garment contributes to the confidence and comfort of the wearer [2,3], while it is a complex interplay between physical and psychological structures, which is critical, in order for one to appear well dressed. The attributes that make a garment personal are precisely those that cannot be designed ahead of time, especially in mass production. Manufacturers' trymany provide customization services, while others allow special orders and specifications or provide a flexible product that, once purchased, can be tuned and tailored by the people who use it. However, garments do not become personal because we have selected some alternatives from a catalogue of choices.

Most of the time we are unable to make up the garments we need, for we lack the tools and expertise, not to mention the time. But when we buy someone else's garment, seldom does it fit our precise requirements. In manufactured design, clothes are configured and made according to particular specifications that many users find irrelevant. Ready-made, purchased clothing, for example, rarely fit each individual perfectly, although they might be close enough to be satisfactory. Fortunately, each individual is free to buy different kinds of clothes and then combine them in whatever way works best for them, reflecting their own personality.

The various ways of dealing with this problem are, either to live with a mass-produced garment and benefit from its lower cost, to customize it, to modify it - which is probably the favourite and most widely followed method to make purchased garments into personal ones, all over the world [4] - to design and construct it on our own or to have it manufactured-to-order.

Although, today, there is a plethora of apparel products offered in the market, certain individuals still find it difficult to achieve a good fit in their clothes. Normally, such individuals should consider having their clothes custom-made for them-at least some of them. It may be the only way for obtaining the fit and quality they want, due to the fact that with custom-made clothes the design or pattern is altered to their exact measurements.

A major issue for having one's clothes custom-made is, usually, their high cost. They may cost no more than what one would pay for good-quality ready-made clothes plus alterationsor sometimes less. Normally, however, the cost can be somewhat more due to the fact that one is paying for a specialized service and one-of-a-kind garments. Other factors also enter in, such as the area of the country where one lives in, the state of the local economy, along with the experience and reputation of the professional and, mostly, the time, which is usually more than it takes to go to the store and buy something off the rack.

Generally, custom-made clothes rely on comparing the pattern with body measurements. An ease allowance is added to the measurements at points where the body moves or expands. After that, the pattern is compared with the corresponding bodyplus-ease measurement. 'Alteration' is the process of changing particular parts of a garment to fit a particular individual. The goal with altering patterns is to achieve well-fitting garments for individuals with non-standard body shapes and types, while with minor adjustments the garment can look as if it were custommade. Successful alterations depend on knowing when to alter and when not to alter, where to begin and how to proceed.

Notwithstanding, educators in patternmaking, instruct their students the correct way to achieve garment fit, which is to create a pattern with the desired fit from the beginning, based on individual body measurements, and not to alter already existing patterns [5,6]. Today, Made-To-Measure garments, normally, are generated via an already established basic pattern block, while the adaptations needed, in order to 'accommodate' the specific body, for which the order is being placed, are added to this basic 
pattern block. After that, the unique garment derived from this 'adapted' basic pattern block is suitable for that specific individual. The final Made-To-Measure garment has to be in total harmony with the individual's silhouette and shape. For many people, any distinctive body features should not be more visible than necessary. It is the actual interplay between the body figure and the garment's final shape that gives a well-fitting dress. A well-fitting garment requires a correctly designed pattern, and of course, the appropriate garment style for the body wearing it. Finding a balance between the body figure, the designed style and the necessary adaptations for accommodating anybody asymmetry leads to a perfect-fitting individual pattern. When designing individual patterns for individuals with asymmetric bodies, the garments should have the appropriate style lines, in order to accommodate the asymmetry. These style lines are crucial not only for the fit, but also for the hang and appearance of the garment.

Today's clothing market is not adapted for people with asymmetric or unusual body dimensions. A method of useroriented product development could possibly solve their problem. Nevertheless, many such people feel that these special garments still emphasise their body asymmetry, in a nonaesthetical way, and would prefer to take the trouble to buy their clothing in conventional retail stores with a much larger choice and make adaptations conforming to their needs. Their clothing requirements are very much dependent on their asymmetry not only regarding the fit and function of the clothing, but also regarding shopping and service in the stores. In combination with other developments in Information Technology (IT) it could be possible to synthesise a new system where the manufacturers and retailers of clothing can co-operate in order to provide service to such users. The solution to the clothing dilemma of the disabled, however, does not lie in coming with, adapting, or altering already purchased clothing, due to the fact that clothing produced with standard patterns do not fit persons with deviating body dimensions and the patterns have to be altered according to individual body dimensions.

This work is licensed under Creative Commons Attribution 4.0 Licens DOI: 10.19080/CTFTTE 2017.01555566
Hence, there are many individuals within the categories elderly, impaired, and/or disabled who have exceptional problems in finding suitable clothes and need specially designed clothing. There are, however, several reasons why the possibilities of this choice are restricted.

Obviously, clothing for all people with asymmetric bodies cannot be the same. When we consider the functionality of a garment, we focus on the physical requirements in dressing, in relation to the particular individual. The inability to dress and undress can rob an individual with a non-standard body configuration of necessary feelings of satisfaction, pride, and self-worth. And even though fit, color, and comfort are important features to consider in the design of a garment, the problem of ease in dressing and undressing is often of greatest importance [7]. Chase \& Quinn [7] suggest that whether the designer of this clothing is an accomplished professional or a skilled home sewer, the goal is the same: the 'marriage of function and aesthetics', the production of functional, yet aesthetically appealing clothing.

\section{References}

1. Entwistle J (2000) The Fashioned Body: Fashion, Dress, and Modern Social Theory, Cambridge: Wiley-Blackwell, United States.

2. Alexander M, Connell LJ, Presley AB (2005) Clothing Fit Preferences of Young Female Adult Consumers. International Journal of Clothing Science and Technology 17(1): 52-64.

3. Klepp IG (2008) Clothes, the body and well-being: What does it mean to feel well dressed? Oslo: National Institute for Consumer Research, pp: $1-30$.

4. Norman D (2004) Emotional Design: Why We Love (or Hate) Everyday Things, Basic Books: New York, USA (A Member of the Perseus Books Group).

5. Joseph-Armstrong H (2000) Patternmaking for Fashion Design. (3 ${ }^{\text {rd }}$ Edn.), (First Published in the United States of America, Upper Saddle River, New Jersey in 1995 by Prentice Hall Publications), London: Prentice-Hall International (UK) Limited.

6. Zamkoff B, Price J (1997) Basic Pattern Skills for Fashion Design. New York: Fairchild Publications, United States.

7. Chase RW, Quinn MD (2003) Design without limits: Designing and sewing for special needs. (Revised First Edition), Fairchild Publications, Inc, New York, United States.

Your next submission with Juniper Publishers
will reach you the below assets
- Quality Editorial service
- Swift Peer Review
- Reprints availability
- E-prints Service
- Manuscript Podcast for convenient understanding
- Global attainment for your research
- Manuscript accessibility in different formats
( Pdf, E-pub, Full Text, Audio)
- Unceasing customer service
Track the below URL for one-step submission
https://juniperpublishers.com/online-submission.php

